\title{
OKULTISME DALAM PELAYANAN PASTORAL
}

\author{
Rahel Jum Juld ${ }^{1}$ \\ I Ketut Enoh ${ }^{2}$
}

\begin{abstract}
ABSTRAK
Tujuan penulisan karya ilmiah ini adalah: Pertama, memberikan pemahaman tentang strategi dan pengaruh okultisme dalam pelayanan. Kedua, menunjukkan bagaimana cara melayani orang-orang yang dikuasai oleh okultisme.

Metode yang digunakan dalam penyusuanan karya ilmiah ini adalah: memakai metode penelitian studi kepustakaan yakni penulis mengambil data-data dari buku-buku perpustakaan dan tulisan-tulisan lainnya yang memiliki hubungan dengan karya ilmiah ini, juga pengalaman penulis dalam pelayanan okultisme merupakan dukungan dalam penulisan karya ilmiah ini.

Adapun kesimpulan karya ilmiah "Okultisme dalam Pelayanan Pastoral" adalah: Pertama, okultisme dalam pelayanan pastoral merupakan bagian yang kait mengait dengan pemberitaan Injil. Manusia harus diinjili supaya menerima Yesus sebagai Tuhan dan Juruselamatnya dan orang yang telah diselamatkan harus juga dilepaskan dari kuasa gelap atau kuasa setan. Kedua, okultisme dalam pelayanan pastoral menjadi sangat penting bagi pelayanan pastoral karena iblis adalah musuh kita. Oleh karena itu, hamba-hamba Tuhan harus yakin bahwa iblis ada dan tetap bekerja memengaruhi umat Tuhan dan hamba-hamba Tuhan harus siap membela umat Tuhan dengan melawan iblis dengan iman yang teguh. Ketiga, penguraian okultisme dalam pelayanan pastoral adalah merupakan acuan yang dapat dijadikan pedoman oleh hamba-hamba Tuhan dalam mengadakan pelepasan umat Tuhan dari kuasa-kuasa gelap, sehingga umat Tuhan menjadi umat pemenang dari kuasa dosa dan iblis.
\end{abstract}

Kata kunci: okultisme, pelayanan pastoral

\footnotetext{
${ }^{1}$ Almuni Sl STT Jaffray Makassar 2013

${ }^{2}$ Dosen Emeritus STT Jaffray Makassar
} 


\section{PENDAHULUAN}

\section{Latar Belakang Masalah}

Pelayanan penggembalaan dikalangan gereja-gereja seringkali kurang memerhatikan pelayanan pelepasan dari kuasa-kuasa roh jahat. Sementara jemaat Tuhan juga tidak mengerti atau tidak tahu bahwa ada roh jahat sedang bekerja diantara mereka. Menurut Warren W. Wiersbe, banyak orang akan terkejut pada saat mengetahui bahwa setan pun masuk gereja. Melalui kekuatan-kekuatan roh jahat, dia benarbenar mengendalikan beberapa gereja ${ }^{3}$. Alkitab Penuntun mengatakan bahwa berbagai kegiatan okultisme yang umum dipakai dalam agama bangsa-bangsa Kanaan, merupakan kekejian bagi Allah dan dilarang oleh-Nya. Orang-orang diantara umat Allah yang melakukan hal-hal itu dibunuh (Imamat 20:27). Perjanjian Baru menyatakan hal yang serupa bahwa orang yang melakukan hal-hal itu tidak akan masuk kerajaan Allah (Galatia 5:20,21)." ${ }^{4}$ Maka penulis menyimpulkan bahwa memang benar roh jahat ada bekerja diantara umat manusia, baik yang beragama Kristen maupun yang bukan beragama Kristen. Karena itu hambahamba Tuhan harus mengetahui bagaimana caranya melepaskan umat Tuhan dari pekerjaan roh-roh jahat.

Roh-roh jahat yang disebut setan dan iblis sebenarnya bekerja diantara manusia sejak manusia jatuh kedalam dosa dan manusia jatuh ke dalam dosa karena hasil pekerjaan roh-roh jahat itu. Iblis selalu berusaha meningkatkan pekerjaannya untuk merebut manusia dari kebenaran. Dalam tabloid bimbingan dan doa kesembuhan ilahi oleh Simon Sampe Randan mengatakan bahwa roh jahat yang disebut iblis dalam bahasa Yunani disebut diabolos berarti penuduh, penfitnah, pengumpat. Setan dalam bahasa Ibrani disebut Sathan. Sathan berarti musuh. Jadi Setan adalah Roh jahat yang bersifat musuh, berjalan meningkatkan sifat permusuhan di kalangan umat Tuhan. ${ }^{5}$ Namun seringkali banyak orang Kristen kurang menyadari bahwa ada Iblis dan Setan yang sedang bekerja diantara mereka. Bukti pekerjaan roh jahat ditengah-tengah manusia sangat nyata. Demikian pula dikalangan orang-orang Kristen. Tidak dapat dipungkiri bahwa ada orang Kristen yang masih dirasuki oleh kuasa-kuasa kegelapan atau roh-roh jahat. Inilah kenyataan dan tantangan yang dihadapi dalam pelayanan penggembalaan masa kini. Pelayan penggembalaan bukan saja pelayanan

\footnotetext{
${ }^{3}$ Wiersbe Warren W. Strategi Setan (Yogyakarta: Yayasan Andi, 1992), 139.

${ }^{4}$ Alkitab Penuntun Hidup Berkelimpahan (Malang: Yayasan Penerbit Gandum Mas, 2000), 304. n.d.), 11.

${ }^{5}$ Simon Sampe Randan, Tabloid Bimbingan Pelepasan dan Doa Kesembuhan Ilahi (n.p,
} 
yang berorientasi pada perkunjungan rumah semata ataupun konseling jemaat, tetapi juga mencakup pelayanan bagi orang-orang yang mengalami dan dikuasai oleh kuasa-kuasa kegelapan. Memperhatikan keadaan ini, penulis merasa tertarik menguraikannya dan mengangkatnya sebagai suatu karya ilmiah dengan judul: "Okultisme Dalam Pelayanan Pastoral."

\section{Pokok Masalah}

Dengan melihat latar belakang di atas, maka yang menjadi pokok masalah dalam karya ilmiah ini adalah: Pertama, apa strategi dan pengaruh okultisme dalam pelayanan? Kedua, bagaimana cara melayani orang-orang yang dikuasai oleh okultisme?

\section{Tujuan Penulisan}

Sesuai dengan masalah pokok yang ada, maka tujuan penulisan ini adalah: Pertama, memberikan pemahaman tentang strategi dan pengaruh okultisme dalam pelayanan. Kedua, menunjukkan bagaimana cara melayani orang-orang yang dikuasai oleh okultisme.

\section{Manfaat Penelitian}

Adapun manfaat dari penulisan karya ilmiah ini adalah sebagai berikut: Pertama, Memberikan pemahaman tentang pengaruh dan pekerjaan roh jahat di dalam kehidupan manusia, Kedua, Memberikan perspektif bagi pelayanan penggembalaan masa kini bagaimana cara melayani orang-orang yang mengalami okultisme.

\section{Metode Penelitian}

Penulis karya ilmiah ini memakai metode penelitian studi kepustakaan yakni penulis mengambil data-data dari buku-buku perpustakaan dan tulisan-tulisan lainnya yang memiliki hubungan dengan karya ilmiah ini, juga pengalaman penulis dalam pelayanan okultisme merupakan dukungan dalam penulisan karya ilmiah ini.

\section{Batasan Penulisan}

Penulis membatasi dengan membahas Okultisme dalam pelayanan pastoral dan untuk mencapai tujuan yang maksimal maka penulis akan memakai strategi yang tepat dalam menghadapi iblis dan roh jahat serta relevansi okultisme dalam pelayanan pastoral masa kini. 


\section{PENGERTIAN UMUM TENTANG OKULTISME DAN PASTORAL}

\section{Definisi Okultisme}

Menurut pendapat H. Soekahar, dalam buku yang berjudul Satanisme dalam pelayanan pastoral mengatakan : "Okultisme sebenarnya berasal dari kata latin occultus, artinya: tersembunyi, rahasia, sial, celaka, gaib, gelap, dan misterius. Jadi okultisme berarti penglibatan diri dengan kuasa, kegelapan, gaib, agar mengalami hal-hal yang rahasia aneh, dan misterius." 6

Dalam buku Ensklopedia Bebas dikatakan: "Okultisme adalah kepercayaan terhadap hal-hal yang supranatural seperti ilmu sihir. Kata okultisme merupakan terjemaahan dari bahasa Inggris, occultism. Kata dasarnya occult berasal dari bahasa latin occultus (rahasia) dan occullerel (tersembunyi) yang merujuk kepada pengetahuan yang rahasia dan tersembunyi."”

\section{Defenisi Pastoral}

Untuk memahami pastoral secara jelas maka penulis akan menjelaskan berdasarkan etimologinya dan berdasarkan pandanganpandangan ahli teologi :

Pertama, berdasarkan etimologi, kata pastoral itu, kata dasarnya pastor (Latin) dan bahasa Yunaninya poimen yang berarti Gembala. Jadi pastoral dapat di sebut juga pastoralia atau poimenikh atau penggembalaan.8 Dalam Injil Yohanes 21:12-15 Yesus memberi pesan kepada Petrus supaya memelihara domba-domba Allah yang akan di tinggalkan oleh Yesus. Yesus mengungkapkan tiga kali bahwa gembalakanlah domba-dombaku. Tiga kali ungkapan gembalakanlah domba-dombaku bermakna bahwa betapa pentingnya menggembalakan domba-domba Allah. Jadi berdasarkan etimologi dan Injil Yohanes maka penulis mengatakan pastoral adalah penggembalaan dan penggembalaan berarti menjaga, memelihara, melindungi, menyelamatkan dari bahaya, membesarkan, dan mendewasakan serta mengembang biakkan dombadomba Allah.

Kedua, Pastoral dilihat dari kata kiasan, poimen (Yunani) menggambarkan orang yang bertindak sebagai gembala jemaat. Hal ini juga memberi makna sebagai pemimpin dan penjaga kawanan domba

\footnotetext{
${ }^{6}$ Soekahar H., Satanisme Dalam Pelayanan Pastoral (Malang: Gandum Mas, 1983),

6.

${ }^{7}$ Kamus, Ensiklopedia. Conkordasi di Internet

${ }^{8}$ Grain Dobbins, dalam John E. Ingouf, Seklumit Tentang Gembala Sidang (Bandung: Lembaga Literatur Baptis, 1988),14.
} 
yaitu jemaat (Kisah Para Rasul 20:18).9 Dalam Kisah Para Rasul 20:28-32 di katakan bahwa Gembala harus menjaga dirinya sendiri dan menjaga seluruh kawananan domba Allah karena Gembalalah yang di tetapkan oleh Roh Kudus menjadi penilik untuk menggembalakan jemaat Allah, karena akan masuk serigala-serigala yang ganas ke tengah-tengah jemaat untuk merampas kawanan domba Allah. Dan akan muncul juga dari tengah-tengah kamu pengajar-pengajar sesat yang akan menyesatkan domba-domba Allah. Dari kebenaran ini penulis menyatakan bahwa pastoral adalah Gembala yang menggembalakan dan memimpin dombadomba Allah yaitu jemaat Tuhan. Gembala juga disebut penilik jemaat yang bertugas menggembalakan dirinya sendiri, bertugas menggembalakan domba Allah yaitu jemaat Tuhan dan juga bertugas mengajarkan ajaran yang benar kepada jemaat Tuhan supaya jemaat Tuhan tidak terpengaruh pada ajaran-ajaran sesat yang akan muncul dari tengah-tengah jemaat. Gembala juga akan melindungi dombadomba Allah dari serangan serigala. Domba Allah di sini adalah jemaat Tuhan dan serigala adalah roh jahat atau Iblis dan Setan itu berarti Gembala harus melindungi jemaat Allah dari serangan roh jahat dan serangan Setan.

Ketiga, Di lihat dari istilah Gembala, Penatua,dan Penilik jemaat merupakan tiga istilah pastoral yang sebenarnya menunjuk kepada satu jabatan yang sama dalam perjanjian baru. Kisah Rasul 20:17-28 mengungkapkan bahwa Penatua, Penilik, dan Gembala adalah satu jabatan dan orangnya sama artinya Hamba Tuhan yang melayani jemaat Tuhan bisa di sebut Penilik jemaat bisa juga di sebut Penatua jemaat, bisa juga di sebut Gembala. Dalam 1 Petrus 5:1-2 tugas Gembala sama dengan tugas Penatua karena kata Penatua, kata Gembala, dan kata Penilik sama bertugas menggembalakan domba-domba Allah. Demikian juga dalam Titus 1:9 istilah Penatua, Penilik, adalah jabatan yang sama adalah istilah Gembala. Jadi penulis menyimpulkan bahwa Pastoral memiliki istilah Gembala, Penatua, dan Penilik merupakan satu jabatan yang sama bertugas menggembalakan domba-domba Allah. Menggembalakan domba-domba Allah berarti menjaga domba Allah dari serangan Iblis, serangan pengajar sesat, juga berarti memimpin jemaat Tuhan kepada seluruh kehendak Allah dan menjaga jemaat Tuhan dari berbagai tantangan yang muncul dari dalam dan keluar.

Keempat, beberapa pendapat ahli teologi: (1) Menurut Thurneysen penggembalaan merupakan sesuatu penerapan khusus Injil kepada anggota jemaat secara pribadi, yaitu berita Injil yang dalam khotbah

${ }^{9}$ M. Bons-Storm, Apakah Penggembalaan itu? (Jakarta: BPK Gunung Mulia, 1988), 
Gereja di sampaikan kepada semua orang. ${ }^{10}$ (2) Menurut J.W. Herfst tugas penggembalaan menolong orang satu persatu untuk menyadari hubungannya dengan Allah dan sesamanya dalam setuasi sendiri. ${ }^{11}$ (3) Menurut H. Faber penggembalaan itu adalah tiap-tiap pekerja yang di dalamnya si pelayan sadar akan akibat yang ditimbulkan oleh percakapan atau khotbah atas kepribadiaan orang yang pada saat itu dihubunginya.

Dari pengertian secara etimologi, dari arti kiasan dari istilah Pastoral dan dari beberapa pendapat ahli Teologia diatas ini maka penulis menyimpulkan bahwa Pastoral atau pengembalaan, atau kepemimpinan merupakan pekerjaan yang dikerjakan oleh satu orang yang biasa digelar Pastor atau Penatua atau Penilik Jemaat atau Gembala Sidang. Dan dari pendapat diatas ini pula penulis menyimpulkan bahwa tugas dan tanggung jawab seorang gembala adalah menjaga, membimbing, memelihara, merawat, menuntun, mengajak, mendisiplinkan dan menghibur domba-domba Allah yaitu jemaat Tuhan. Secara khusus domba-domba Allah atau jemaat Tuhan menghadapi musuhnya yaitu roh jahat yang disebut iblis dan setan, karena itu gembala menjaga jemaat Tuhan dari serangan Iblis, gembala membimbing jemaat Tuhan untuk membedakan pekerjaan roh kudus dan pekerjaan roh jahat dan memelihara jemaat sehingga tidak akan terpengaruh praktek-praktek okultisme.

\section{STRATEGI DAN PENGARUH OKULTISME DALAM PELAYANAN}

Penulis akan mengungkapkan strategi yang dipakai oleh Iblis untuk memengaruhi manusia. Iblis atau setan adalah penguasa dalam okultisme. Strategi yang dipakai iblis untuk mengacaukan kehidupan manusia perlu dikenal dan dipahami dengan baik sehingga pelayanan pastoral yang tepat dapat diambil. Musuh iblis menurut Efesus 6:12 adalah manusia. Kalau manusia adalah musuh iblis itu berarti bahwa strategi yang akan di pakai Iblis untuk menaklukkan musuhnya adalah strategi yang di pakai untuk menguasai manusia.

\section{Strategi Iblis}

Strategi iblis memengaruhi musuhnya karena yang bekerja dalam okultisme adalah iblis atau setan sehingga tidak salah kalau penulis mengatakan Strategi Okultisme sama dengan Strategi iblis atau setan

\footnotetext{
${ }^{10}$ Nehemia Mimery, Rahasia Tentang Penggembalaan (Jakarta: Mimery Press,n.d) 6.

${ }^{11}$ Ibid., 6.
} 
untuk mempengaruhi musuh-musuhnya. Menurut Warren W. Wiersbe, bahwa ada empat strategi yang dipakai oleh Iblis atau di pakai dalam okultisme untuk mempengaruhi kehidupan manusia antara lain:

\section{Strategi Pertama Ialah Menipu}

Sasaran setan sang penipu adalah pikiran. Pikiran adalah bagian dari citra Allah. Melalui pikiran, Allah berkomunikasi dan menyatakan kehendaknya kepada manusia. Iblis mengetahui bahwa kalau pikiran manusia tidak di ganggu ia akan tetap mengandalkan Tuhan dan percaya pada Firman Tuhan. Dalam Kejadian 3:1 - 7, iblis memengaruhi pikiran Hawa sehingga ia meragukan Firman Tuhan dan memercayai perkataanperkataan iblis. Tujuan iblis menyerang pikiran manusia ialah supaya manusia buta terhadap kehendak Allah.

Pertahanan menghadapi sang penipu ialah Firman Allah yang di ilhamkan. Hanya Firman Allah yang diilhamkan yang dapat mengalahkan dusta Iblis, hikmat manusia tidak sebanding dengan kelicikan iblis karena itu adalah Firman Allah merupakan perlindungan yang aman bagi kita. Pada waktu Yesus di cobai Ia memakai Firman Allah sebagai pertahanan (Matius 4:1-11). ${ }^{12}$

\section{Strategi yang Kedua Ialah Mendatangkan Penderitaan}

Bila setan atau iblis tidak dapat mengalahkan manusia dengan memperdayakan pikirannya atau dengan memengaruhi pikirannya, maka ia akan berusaha merusak tubuh manusia. Contoh jelas sekali dalam Alkitab tentang kehidupan Ayub, Ayub kehilangan buah hatinya, kehilangan kesehatan tubuhnya di landa penyakit menjijikkan segala harta miliknya habis lenyap. Bahkan dalam perjanjian baru Iblis menyebabkan seorang laki-laki bisu (Matius 9:32-33), seorang perempuan menjadi bungkuk (Lukas 13:11-17), ia menyerang seorang anak sehingga anak itu jatuh kedalam air dan api (Matius 17:14-18).

Senjata iblis ialah mendatangkan penderitaan atau membuat tubuh menjadi sakit. Iblis berusaha menguasai keadaan di sekitar tubuh manusia supaya mereka mengalami penderitaan. Keadaan ini dapat di lihat dalam keadaan Ayub. Tujuan Iblis perusak ialah supaya manusia tidak tekun terhadap kehendak Allah. Ketekunan merupakan sesuatu yang sangat penting dalam kehidupan Kristen. Jika kita tidak tekun maka kita tidak dapat belajar banyak dari kehendak Allah yang ingin di sampaikan itulah sebabnya Yakobus 1:2-4 mengatakan Saudarasaudaraku, anggaplah suatu kebahagiaan apabila kamu jatuh dalam berbagai-bagai pencobaan, sebab kamu tahu bahwa ujian terhadap

\footnotetext{
${ }^{12}$ Warren W. Wiebe, Strategi Setan (Yogyakarta: Yayasan ANDI, 1992), 28.
} 
imanmu itu menghasilkan ketekunan. Dan biarkan ketekunan itu memperoleh buah yang matang supaya kamu menjadi sempurna dan utuh dan tak kekurangan sesuatu apapun.

\section{Strategi yang Ketiga Ialah Membuat Sombong}

Senjata yang dipakai oleh iblis adalah kesombongan. Salah satu bahaya akibat mencapai kesuksesan yang besar ialah kesombongan karena kesombongan memuliakan manusia dan merampok kemuliaan Allah. Itulah sebabnya Iblis memakai kesombongan sebagai senjata yang paling ampuh.

Pertahanan menghadapi setan adalah Roh Allah yang diam dalam diri manusia. Kesombongan adalah senjata yang paling ampuh dan hanya kuasa yang lebih kuatlah yang dapat memberikan kemenangan kepada manusia. Kuasa itu hanya bersumber dari Roh Kudus, hanya Allah Roh Kudus yang bekerja dalam diri manusia yang dapat mengontrol kehendak manusia, dan memampukan manusia menyenangkan Allah. Kebenaran Firman Tuhan dalam I Yohanes 4:4 mengatakan bahwa, "Kamu berasal dari Allah, anak-anakku, dan kamu telah mengalahkan nabi-nabi palsu itu; sebab Roh yang ada di dalam kamu, lebih besar dari pada roh yang ada di dalam dunia." Didalam ayat ini kita tahu bahwa orang yang berasal dari Allah, Roh Allah ada didalam dia dan Roh Allah itu adalah Roh yang lebih besar dari roh didalam dunia yaitu roh Setan yang disebut nabi-nabi palsu. Dengan Roh Allah, anak-anak Allah dapat mengalahkan roh-roh Iblis. ${ }^{13}$

\section{Strategi Yang Keempat Ialah Mendakwa}

Setan mempunyai suatu tipu daya yang akan membuat orang Kristen tidak taat sehingga mengalami kekalahan ganda. Dalam kitab Zakharia 3 di ungkapkan tentang dakwaan imam besar Yosua yang berdiri di hadapan malaikat Tuhan sedang Iblis berdiri di sebelah kanannya untuk mendakwa dia.

Sasaran setan ialah hati dan nurani manusia. Dalam kitab Zakharia 3 Allah sebagai hakim, imam besar Yosua sebagai yang terdakwa dan setan menjadi pendakwa yang mencoba membuktikan kesalahan Yosua. Tampaknya setan mempunyai suatu perkara karena Yosua mengunakan pakaian kotor. Biasanya Imam besar selalu mengenakan pakaian yang bersih tetapi Yosua sebagai Imam besar memakai pakaian kotor. Yosua mewakili umat di hadapan Allah dan umat dalam keadaan berdosa, sehingga setan mengerti bahwa ia berdosa dan setan memprotes kepada Allah dengan mengatakan Israel harus dihakimi.

\footnotetext{
${ }^{13}$ Warren W. Wiebe, 80.
} 
Pertahanan menghadapi pendakwa adalah pembelaan anak-anak Allah. Setan selalu berdiri di sebelah kanan kita sambil menuduh tetapi Yesus Kristus berdiri di sebelah kanan Allah untuk bersyafaat bagi anakanakNya. Menurut 1 Yohanes 2 : 1 bahwa jika seorang berbuat doa kita mempunyai seorang perantara kepada Bapa yaitu Yesus Kristus yang adil. Yesus Kristus menjadi pengantara bagi kita, dan memberikan anugerah bagi kita yang kita butuhkan pada waktu kita mengalami pencobaan dan ujian. Bila dengan iman kita berpaling kepadaNya dan datang ketahta kasih karunia Tuhan akan membawa kita kepada kemenangan. Bila kita menyerah pada pencobaan dan dosa, Tuhan Yesus akan bertindak sebagai pembela yang mengampuni dan memulihkan persekutuan dengan Allah. Apakah Allah menutup mata pada kenyataan dosa Yosua, Allah tidak pernah membela dosa anak-anakNya tetapi Ia akan membela anak-anakNya.

\section{Pengaruh Iblis Dalam Pelayanan}

Okultisme sangat kuat mempengaruhi kehidupan manusia sejak manusia ada. Adam dan Hawa di Taman Eden, mulai di pengaruhi oleh Iblis dengan menyerang pikirannya sehingga mereka meragukan Firman Allah dan tidak memercayai perkataan Allah serta lebih memercayai perkataan-perkataan Iblis. Karena mereka sudah meragukan Firman Allah dan lebih memercayai perkataan Iblis, maka mereka mengambil buah yang terlarang dan makan. Sesudah mereka makan baru mereka sadar bahwa telah di tipu oleh Iblis (Kejadian 3: 1-12). Pada masa Yesus Kristus Iblis mencoba mempengaruhi Yesus dengan memakai metode penyerangan melalui kebutuhan tubuh jasmani dengan menjadikan batu menjadi roti tapi Iblis gagal. Iblis mencoba memengaruhi Yesus dengan metode penyerangan melalui kepopuleran, dengan menyuruh Yesus melompat dari bumbungan bait Allah tetapi Iblis gagal. Iblis mempengaruhi Yesus dengan memakai metode yang ke tiga yakni mempengaruhi Yesus dengan harta dunia dengan membawa Yesus ke gunung yang tinggi dan Iblis memperlihatkan keindahan seluruh alam ini, kemudian ia menawarkan kepada Yesus seluruh dunia ini akan ku berikan kepadaMu apabila Engkau tunduk mnyembah kepadaku tetapi Iblis tetap gagal (Matius 4:1-11).

\section{Pengaruh Iblis Pada Masa Pelayanan Yesus Kristus}

Keberhasilan iblis menggoda orang-orang pilihan Tuhan dari masa ke masa maka Iblis juga bekerja keras memengaruhi Yesus maupun murid-murid-Nya:

Pertama, Iblis memengaruhi Yesus dengan menyuruhnya membuat batu menjadi roti tetapi Yesus tidak terpengaruh mengikuti kemauan Iblis (Matius 4:1-4). Kedua, Iblis memengaruhi Yesus untuk melompat 
dari bumbungan bait Allah tetapi Yesus tidak terpengaruh untuk melompat mengikuti kemauan Iblis (Matius 4:5-7). Ketiga, Iblis memengaruhi Yesus dengan memperlihatkan semua kerajaan dunia sebagai milik Iblis dan Iblis akan memberikan kepada Yesus apabila Yesus sujud menyembah Iblis. Pengaruh ketiga ini pun Iblis gagal. Keempat, Iblis memengaruhi Yudas Iskariot sehingga ia menghianati Yesus dengan menerima uang bayaran sebesar tiga puluh perak dari Imam-imam kepala dan ia menyerahkan Yesus kepada Imam-imam kepala untuk disalibkan (Matius 26:14-16). Dalam Lukas 22:23 di mengatakan "Masuklah Iblis kedalam Yudas yang bernama Iskariot seorang dari kedua belas murid itu". Dan dalam Yohanes 13:27 dimengatakan: "dan sesuda Yudas menerima roti itu, ia kemasukan Iblis". Maka Yesus berkata kepadanya katanya : "Apakah yang hendak kau perbuat, perbuatlah segera." Kelima, banyak orang-orang sakit di rasuk Setan dan di bawah kepada Yesus untuk di sembuhkan (Matius 8:16-17).

\section{Pengaruh Iblis Pada Masa Pelayanan Murid-murid Yesus}

Murid-murid Yesus adalah orang-orang yang dipilih khusus oleh Yesus Kristus untuk melanjutkan pekerjaan Kristus didunia ini, sebelum Kristus naik kesurga dalam Matius 10:1 dikatakan: "Yesus memanggil kedua belas murid-muridNya dan memberi kuasa kepada mereka untuk mengusir roh-roh jahat untuk melenyapkan segala penyakit dan segala kelemahan." Dalam ayat ini penulis melihat bahwa Yesus sudah tahu apa yang akan dihadapi murid-murid sebagai generasi penerus pelayanan, yakni pengaruh kuasa okultisme yang akan menatang mereka. Karena itu Yesus mengumpulkan murid-murid-Nya dan memberikan kuasa: Kuasa untuk mengusir roh-roh jahat, kuasa untuk melenyapkan segala penyakit, kuasa untuk melenyapkan segala kelemahan.

Philipus pergi ke Samaria memberitakan Injil dan banyak orang percaya kepada Yesus, disembuhkan dari penyakit dan dilepaskan dari kuasa-kuasa roh jahat. Di Samaria ada seorang ahli sihir atau pemegang kuasa okultisme mempengaruhi masyarakat Samaria sehingga masyarakat Samaria menganggap pemegang kuasa Okultisme itu sebagai kuasa besar dari Allah pada hal ia mempengaruhi masyarakat dengan kuasa okultisme dan bukan dengan kuasa Allah. Menurut Adina Chapman bahwa,

Bahwa setelah kematian Stefanus jemaat di Yerusalem dianiyaya (Kisah Para rasul 8:1-3,Kis 11:19) oleh karena penganiayaan ini, orang-orang percaya melarikan diri kekota-kota yang lain. Kemana pun mereka pergi, kesitu mereka membawa Injil Tuhan. Dengan 
demikian Injil itu tersebar kemana-mana. Strategi Iblis yang tiga berganda untuk mengalangi pekabaran Injil dan perkembangan jemaat yakni para Rasul di penjarakan, Iblis memakai beberapa anggota untuk menjalankan tipu daya dan kesibukan para Rasul menjadi penghalang dalam penginjilan. ${ }^{14}$

Apa yang diungkapkan oleh Adina Chapman ini bahwa setelah Stefanus mati penganiayaan orang Kristen menyebabkan Injil tersebar dari Yerusalem, Yudea, Samaria, dan sampai ke ujung bumi. Namun Iblis memakai tiga strategi untuk menghalangi pertumbuhan jemaat dan kemajuan pemberitaan Injil. Strategi yang di pakai Iblis adalah menangkap dan memenjarakan para Rasul. Iblis memakai tipu daya dan Iblis memakai kesibukan rohani untuk menghalangi pemberitaan Injil.

\section{Pengaruh Iblis Dalam Pelayanan Pastoral Sekarang}

Pada waktu Yesus dicobai oleh Iblis, Iblis tidak dapat mengalahkan Yesus, tetapi Iblis mengatakan dalam Lukas 4:13 "Sesudah Iblis mengakhiri semua pencobaan itu, ia mundur dari padaNya dan menunggu waktu yang baik." Iblis menunggu waktu yang baik berarti Iblis tidak merasa kalah dan ia tetap menantikan waktu yang baik. Waktu yang baik bagi Iblis ialah semua kelemahan-kelemahan orang Kristen dan sejak masa Tuhan Yesus sampai sekarang Iblis memakai kelemahan-kelemahan orang Kristen untuk menghancurkan orang Kristen. Tetapi kebenaran dalam Markus 16:17-18 mengatakan bahwa, "Tanda-tanda ini akan menyertai orang-orang yang percaya: mereka akan mengusir setan-setan demi namaKu, mereka akan berbicara dalam bahasa yang baru bagi mereka, mereka akan memegang ular, dan sekalipun mereka minum racun maut, mereka tidak akan mendapat celaka; mereka akan meletakkan tangannya atas orang sakit, dan orang itu akan sembuh."

Dari ayat ini, penulis menyatakan bahwa Tuhan Yesus melengkapi orang percaya dengan tanda-tanda sebagai orang percaya dengan kuasa untuk mengusir roh-roh jahat demi nama Yesus, mereka akan berbicara dalam bahasa baru bagi mereka, dan mereka memegang ular dan minum racun maut dan tidak apa-apa, kemudian mereka meletakkan tangannya atas orang sakit dan orang sakit itu akan sembuh. Ayat ini pula merupakan dasar bagi orang-orang percaya untuk melayani anak-anak Tuhan yang di kuasai oleh okultisme. Yakobus 4:7 mengatakan Tunduklah kepada Allah dan lawanlah Iblis maka ia akan lari dari padamu.

\section{7), 48 .}

${ }^{14}$ Chapman Adina. Pengantar Perjanjian Baru (Bandung: Yayasan Kalam Hidup, 
Menurut Mary K. Baxter Dr T.L Lowery : "Banyak penderitaan yang di alami oleh umat manusia yang sering kali dianggap sebagai ketegangan syaraf sesungguhnya merupakan pekerjaan kuasa-kuasa gelap. Banyak kecelakaan yang kita anggap sebagai kebetulan atau kejadian yang tidak dapat di hindarkan, sebenarnya merupakan pekerjaan roh-roh jahat." 15

Menurut John dan Mark Sandford, "ia mengertakkan giginya dan berjanji pada dirinya sendiri, kali ini saya harus berusaha duduk di kebaktian sampai selesai kemudian sebagaimana yang terjadi setiap hari minggu suara-suara berdatangan, Allah itu tidak ada. Engkau menyiayiakan waktu saja." 16

Dari pendapat Mary K. Baxter Dr T.L Lowery dan pendapat John dan Mark Sandford dapat dijelaskan bahwa benar ada banyak orang sakit tidak mengetahui bahwa penyakit itu adalah pekerjaan Iblis atau roh jahat, ada banyak orang mendapat kecelakaan tetapi tidak mengetahui bahwa itu pekerjaan roh jahat sehingga roh jahat tetap membuat orang menderita. Ada banyak juga orang pergi ke gereja dan duduk di dalam kebaktian dan mendengar suara-suara Allah itu tidak ada bahkan ada banyak orang yang susah masuk gereja karena pekerjaan roh-roh jahat. Dari kedua pendapat di atas ini penulis menyadari bahwa gereja membutuhkan tanda-tanda orang percaya supaya dapat menolong anggota jemaat yang mengalami penyakit dari roh jahat, dapat menolong anggota jemaat yang susah masuk gereja karena pekerjaan dari roh jahat.

\section{CARA MELAYANI ORANG-ORANG YANG DIKUASAI OKULTISME}

\section{Cara Yesus Melayani Orang Yang Dikuasai Roh Jahat}

Memerhatikan Kitab-kitab Injil maka akan ditemukan cara-cara Yesus melayani orang sakit. Dalam penyembuhan yang dilakukan oleh Yesus bukan saja penyembuhan penyakit yang bersifat alamiah tetapi juga penyembuhan dari penyakit yang bersifat domonis. Penyakit yang bersifat alamiah ialah buta, tuli, lumpuh, bisu, demam dan sebagainya. Penyakit yang bersifat domonis, kerasukan Setan, penyakit fisik yang disebabkan oleh serangan Iblis, sakit ayan, gila, dan sebagainya. Penyakit yang bersifat alamiah dan bersifat domonis dilayani oleh Yesus dengan cara:

\footnotetext{
${ }^{15}$ Baxter Mary K, Alam Roh (Jakarta: Light Publishing, 2000), 64.

16 Sandford Mark \& John, Pelepasan \& Penyembuhan Batiniah (Jakarta: Nafiri Gabriel, 1999), 91.
} 
Pertama, Yesus menjaga anggota tubuh yang sakit, menumpangkan tangannya atas mereka dan mempergunakan ludah (Markus 7:31-37, 8:22-26). Kedua, Yesus memegang tangan si sakit dan membangunkan dia dari pembaringannya (Markus 1:31,5:41,9:27). Ketiga, Yesus menyembuhkan orang yang dirasuk Setan dengan hardikan yang berkuasa (Markus 1:21-27). Keempat, Yesus menyembuhkan orang sakit sesuai kepercayaan orang sakit akan kuasa Yesus Kristus (Markus 1:4041). Kelima, Yesus menyembuhkan dengan jamahan tangannya serta menyatakan kehendaknya (Markus 1:41). Keenam, Yesus menyembuhkan si sakit agar dia dapat mengenal Yesus sebagai Anak Allah dan menyembahnya (Yohanes 9:1-41). Ketujuh, ada kalanya dalam penyembuhan,Tuhan Yesus menyatakan bahwa iman merekalah yang menyembuhkan (Markus 9:14-27, Matius 9:27-31).

Dari ayat-ayat di atas penulis menyimpulkan bahwa Tuhan Yesus menyembuhkan orang sakit baik yang besifat alamiah maupun yang bersifat demonis dengan cara menjamah tubuh yang sakit, menumpangkan tangan atas orang sakit, mempergunakan ludah, memegang tangan si sakit, dan membangunkan dia, dan dengan hardikan yang berkuasa.

\section{Cara Rasul Melayani Orang yang Dikuasai Roh Jahat}

Sebelum Yesus terangkat ke sorga, Ia telah memperlengkapi murid-muridnya dengan kuasa untuk mengusir roh-roh jahat, untuk memberitakan Injil kerajaan Allah dan menyembuhkan orang-orang sakit, dan sesudah Yesus naik ke sorga murid-murid-Nya yang disebut Rasul-rasul melanjutkan pelayanannya di dunia ini.

Pertama, Petrus menyembuhkan orang lumpuh dengan menuntun orang sakit, umtuk berharap kepada Yesus Kristus ( Kisah Para Rasul 3:1-6). Kedua, Petrus menyembuhkan orang lumpuh demi nama Yesus, dan mengangkat berdiri si lumpuh (Kisah Para Rasul 3:7). Ketiga, Orang-orang sakit sembuh karena kena bayang-bayang Petrus (Kisah Para Rasul 5:14-16). Keempat, Filipus di Samaria menyembuhkan orang sakit dalam nama Yesus (Kisah Para Rasul 9:10-11). Kelima, Petrus menyembuhkan Eneas dengan berkata Yesus Kristus datang menyembuhkan engkau, bangunlah dan bereskan tempat tidurmu (Kisah Para Rasul 9:33-35). Keenam, Paulus menyembuhkan seorang lumpuh di Nistra dengan berkata, "Berdiri tegak di atas kakimu (Kisah Para Rasul 14:8-10). Ketujuh, Paulus mengusir Setan yang menguasai perempuan yang mempunyai kemampuan mediumistic dengan jalan menengking setan sampai keluar ( Kisah Para Rasul 16:17-19). Kedelapan, Tuhan berkenan memakai sapu tangan atau kain milik Paulus menjadi alat penyembuhan. (Kisah Para Rasul 28:8). Kesembilan, Menurut 
Yakobus sebelum orang didoakan atau disembuhkan harus mengakui dosanya terlebih dahulu. Kesepuluh, murid-murid Yesus menghancurkan pekerjaan Setan dengan menggumpulkan kitab-kitab ahli sihir dan membakarnya (Kisah Para Rasul 19:19).

Berdasarkan ayat-ayat yang, di atas maka penulis menyimpulkan bahwa Rasul-rasul memakai cara sesuai yang diperintahkan yakni mengusir Setan demi nama Yesus, menuntun orang untuk percaya Yesus, mengakui dosanya, dan meyerahkan benda-benda Iblis untuk dibakar.

Jadi pelayanan murid Yesus atau Rasul-rasul penulis menyimpulkan bahwa ini adalah pelayanan Tuhan Yesus yang di lanjutkan oleh murid-muridNya karena Yesus telah memanggil mereka dan memberikan kuasa untuk mengusir roh-roh jahat melenyapkan segala penyakit, melenyapkan berbagai kelemahan dan memberitakan Injil Kerajaan Allah. Rasul-rasul tersebar memberitakan Injil, mengusir roh-roh jahat, menyembuhkan orang sakit, dan menguatkan orang yang lemah.

\section{Hamba-hamba Tuhan Melayani Orang Yang dikuasai roh jahat}

Hamba-hamba Tuhan melayani orang-orang yang dikuasai roh-roh jahat karena berpedoman pada Markus 16:17-18 yang berbunyi :

"Tanda-tanda ini akan menyertai orang-orang percaya; mereka akan mengusir setan-setan demi Nama-Ku, mereka akan berbicara dalam bahasa-bahasa baru bagi mereka, mereka akan memegang ular, dan sekalipun mereka minum racun maut mereka tidak akan mendapat celaka, mereka akan meletakkan tangannya atas orang sakit dan orang sakit akan sembuh."

Menurut Mery K. Baxter dalam buku sebuah penglihatan tentang alam roh menyatakan bahwa:

"Kita semua siap untuk ketemu muka dengan Tuhan. Dengan segenap hati, supaya mendorong anda untuk mempersiapkan diri karena itu berjaga-jagalah sebab kamu tidak tahu akan hari maupun saatnya Yesus Kristus akan datang kembali, dan Ia akan datang segera. Saya ingin anda siap. Jika anda belum pernah menerima Yesus Kristus sebagai Tuhan dan Juruselamat menurut Firman Tuhan dalam (Yohanes 3:16, Roma 10:9-10, 13). Sekarang marilah kita panjatkan doa ini Bapa dalam nama Yesus Kristus aku datang kepadaMu, sebagaimana adanya aku yaitu seorang berdosa, aku telah berdosa terhadap Engkau, Tuhan, dan terhadap sorga, aku mohon terhadapMu Tuhan Yesus untuk mengampuni aku dan aku mengundang Engkau masuk dalam hatiku, dan menyelamatkan jiwaku biarlah aku di lahirkan kembali oleh Roh Tuhan. Aku mempersembahkan hidupku padaMu Ya Tuhan, aku sungguh- 
sungguh percaya bahwa Engkau anak Allah. Aku mempersembahkan rasa syukur, pujian, dan penghormatan karena Engkau telah menebus aku dengan darahMu, yang berharga. Amin Jika anda telah memanjatkan doa ini bersama saya dan sungguh-sungguh percaya dengan doa ini sekarang anda sudah di selamatkan, anda telah memohon pada Yesus kristus untuk masuk ke dalam hati anda mulailah mengakui dengan mulut anda dan pujilah Dia. Segala Pujian dan Kehormatan bagi Tuhan. ${ }^{17}$

Menurut A. B. Simpson dalam buku Injil Empat Berganda bahwa:

Sepanjang sejarah, sejak zaman Irenius hingga kini, terdapat bukti-bukti dari kesembuhan Ilahi. Sejumlah orang yang tak tepermanai banyaknya, yang telah mengalami kesembuhan ilahi mengatakan dengan suara bulat, "Yesus Kristus tetap sama, baik kemarin maupun hari ini dan sampai selama-lamanya" (Ibrani 13:8). Selama abad pertengahan Gereja memercayai kebenaran ini dan mengajarkannya. Orang-orang Kristen Walddenzen berpegang pada penyembuhan ilahi ini sebagai salah satu asas iman mereka itu. Masa-masa permulaan zaman reformasi penuh dengan peristiwa-peristiwa penyembuhan ilahi kehidupan Luther, Baxter, Fox, Whitefield, John Wesley berisi bukti-bukti yang jelas bahwa mereka percaya akan kebenaran ini. Tambahan pula ada banyak saksi Tuhan yang tersebar di seluruh Eropa hingga ke daerah-daerah utusan Injil yang jauh-jauh yang telah memaklumkan pengalamannya akan kuasa kesembuhan Ilahi oleh Yesus Kristus di dalam hidup mereka. Saksi-saksi tentang penyembuhan itu tidak berkurang banyaknya di Amerika."

Simpson mengatakan sejumlah orang yang tertepamanai banyaknya atau tidak terhitung banyaknya yang telah mengalami kesembuhan ilahi meraka yakin bahwa Yesus tetap sama baik kemarin maupun hari ini sampai selama-lamanya. Artinya dulu waktu Yesus ada di dunia ia membuat kesembuhan ilahi dan banyak orang sakit disembuhkan serta banyak orang kerasukan setan di sembuhkan, demikian juga pada masa pelayanan murid-murid Yesus atau Rasul-rasul Yesus Kristus banyak orang mengalami kesembuhan ilahi, di sembuhkan dari penyakit dan di bebaskan dari kuasa iblis serta disembuhkan, demikian juga berlaku sejak zaman Irenius sampai sekarang ada banyak orang mendapat kesembuhan ilahi, disembuhkan dari penyakit,

\footnotetext{
${ }^{17}$ Baxter Mary K. Alam Roh (Jakarta: Light Publishing, 2000), 165 - 166.

18 A.B. Simpson, Injil Empat Berganda (Bandung: Yayasan Kalam Hidup. 1993), 37.
} 
dibebaskan dari kuasa Iblis dan disembuhkan. Sehingga Simpson mengatakan saksi-saksi penyembuhan tidak kurang jumlahnya di Amerika.

\section{Pengalaman Penulis Dalam Pelayanan}

Sebelum penulis menulis karya tulis ini sudah sering teribat dalam pelayanan orang-orang yang dikuasai oleh Iblis. Pada waktu penulis sedang menulis karya tulis ini banyak orang yang sakit dibawah ke rumah dan dibimbing, dilepaskan dari kuasa roh-roh jahat sehingga dalam penulisan karya tulis ini penulis akan mengungkapkan beberapa pelayanan sebagai pengalaman penulis dalam pelayanan okultisme, antara lain:

1. Pada Tanggal 24 April 201l, kami melayani sepasang suami istri yang sudah 2 tahun menikah tetapi belum mendapat anak. Nama suaminya Dani dan nama istrinya Sinta. Pada waktu sepasang suami istri ini dibimbing dan didoakan, mereka kerasukan setan dan setannya berbicara bahwa ia kecewa kepada perempuan sebab menolak cintanya akhirnya ia mengguna-gunai mereka berdua sehingga tidak bisa mendapatkan anak. Sesudah roh jahat berbicara. penulis dan kawan-kawan berdoa dan mengusir roh jahat itu dan roh jahat itu keluar, maka keadaan kedua orang itu menjadi baik dan sehat. 3 bulan kemudian Dani dan Sinta datang kembali memberitahukan bahwa Sinta sudah hamil 2 bulan.

2. Pada Tanggal 20 November 201l, penulis bersama dengan bapak penulis melayani seorang anak yang bernama Sapu.' Sapu' ini baru kelas 1 SMP Makale Tana Toraja. Sapu' sakit dan dirujuk ke Rumah Sakit Jiwa Makassar. Karena tidak ada perubahan maka Sapu' dikeluarkan dari Rumah sakit dan dibawah ke rumah penulis untuk didoakan. Sapu' didoakan pertama, kedua, belum ada apa-apa tetapi waktu didoakan ketiga kalinya baru ketahuan bahwa roh jahat yang menguasai anak itu. Roh jahat berbicara melalui Sapu' bahwa semua pakaiannya sudah diisi dengan mantra-mantra yang akan memberanikan anak itu melawan siapa saja. Setelah diketahui bahwa semua pakaiannya sudah dikuasai oleh mantra-mantara maka disarankan kepada keluarga supaya pakaiannya dibakar dan belikan pakaian baru. Sesudah pakaiannya dibakar si Sapu' mulai baik, mulai berbicara dan sudah mulai menyanyi waktu disuruh menyanyi. Beberapa hari kemudian keluarga datang minta ijin untuk pulang ke Toraja karena Sapu' telah sembuh.

3. Pada Tanggal 15 Februari 2013, ada seorang ibu yang bernama Anty datang ke rumah penulis meminta bimbingan karena sudah lama menikah dan tidak mendapat anak. Sesudah dibimbing dan didoakan ternyata ada roh jahat yang dipakai mengikat 
kandungannya sehingga tidak bisa punya anak. Ibu ini dibimbing dan didoakan oleh penulis bersama kawan-kawan akhirnya roh jahat itu keluar dan puji Tuhan sekarang sedang hamil.

4. Pada Tanggal 18 Mei 2013, Penulis dan kawan-kawan melayani seorang bapak yang bernama Samuel P yang sudah 3 tahun sakit dan lumpuh sehingga ia hanya memakai kursi roda. Dan pada waktu dilayani pertama, dibimbing, didoakan ketahuan bahwa yang membuat dia lumpuh adalah akibat disantet orang. Penulis dan kawan-kawan berdoa dan mengadakan pelepasan dari roh jahat akhirnya bapak itu langsung berjalan.

5. Pada Tanggal 20 Mei 2013, melayani seorang ibu yang bernama Sol Vince A yang sudah dioperasi di Rumah Sakit Wahidin dan akhirnya lumpuh. Ibu Sol Vince berasal dari Papua memakai kursi roda karena lumpuh. Tanggal 20 Mei 2013 penulis dan kawankawan mendoakan dia ternyata penyakitnya berasal dari roh-roh jahat dan setelah didoakan, roh jahat keluar dan ibu Sol Vince bisa berdiri dan berjalan namun kaki kirinya dan tangan kirinya belum kuat betul tetapi Puji Tuhan, dia sudah tidak memakai kursi roda.

Dengan pengalaman penulis ini, penulis menemukan bahwa ada orang lumpuh, ada orang yang tidak mendapat anak, ada orang badannya kaku, ada orang yang tidak bisa berbicara, ada orang yang takut ke Gereja, dan ada orang yang takut mandi semuanya ini adalah pekerjaan penguasa kegelapan atau roh-roh jahat. Roh-roh jahat masuk dalam diri manusia karena manusia berada dalam keadaan kosong (Matius 12:44). Kosong berarti tidak tegak didalam iman dan tidak yakin bahwa Yesus ada didalam dirinya.

\section{Cara Melayani Orang Yang Dikuasai Roh jahat Masa Kini}

Metode pelayanan Yesus, murid-muridnya dan Hamba-hamba Tuhan di atas maka penulis merumuskan cara pelayanan yang akan dipraktikkan dalam pelayanan.

Pertama, susunan pelayanan pelepasan dari kuasa iblis dan doa kesembuhan ilahi. Pendahuluan

1) Yang sakit dan keluarga memahami cara pelayanan

2) Mengisi formulir pernyataan siap menerima pelayanan

3) Doa pembukaan.

Kedua, bimbingan mengenal penyakit yang digumuli.

1) Penyakit yang berasal dari Iblis

2) Penyakit biasa

Ketiga, bimbingan secara umum.

1) Yang sakit dibimbing mengenal penyebab penyakit

2) Yang sakit dibimbing mengenal yang menyembuhkan

3) Yang sakit dibimbing mengakui dosa 
Keempat, doa untuk orang sakit.

1) Yang sakit dibimbing berdoa pengampunan dosa dan doa menerima Yesus

2) Pengolesan dengan minyak

3) Doa pelepasan dari kuasa Iblis

4) Doa pemulihan

Kelima, bimbingan lanjutan.

1) Menjelaskan Matius 12:43-45, 2 Korintus 13:5, dan Yakobus 4:7

2) Mengatur waktu untuk pertemuan berikutnya

3) Doa penutup.

Susunan pelayanan ini bagi penulis sangat menolong baik bagi yang melayani maupun kepada yang dilayani. Yang melayani memiliki pedoman tetap dan teratur sedangkan yang baru dilayani akan melihat susunan pelayanan dan kalau setuju ia akan menanda tangani formulir pernyataan siap di layani secara Kristen.

Penulis mempersiapkan formulir pernyataan menerima pelayanan secara rohani karena ada banyak pengalaman Hamba-hamba Tuhan dalam melayani orang sakit dan ada kalanya keluarga keberatan, ada kalanya Gereja keberatan, dan ada kalanya pemimpin agamanya keberatan. Dan kalau dibuatkan pernyataan kita sebagai pelayan ada pengangan bahwa tidak sembarangan melayani orang, tetapi kita melayani karena kemauannya sendiri dan permintaannya sendiri.

Di bawah ini ada contoh formulir pernyataan :

Formulir Pernyataan Menerima Pelayanan Secara Kristiani

Saya yang bertanda tangan di bawah ini :

NAMA
UMUR
JENIS KELAMIN
ALAMAT
PEKERJAAN
AGAMA/GEREJA
NO TLP/HP

Menyatakan bahwa saya dengan kemauan sendiri meminta pelayanan secara Kristiani dari Hamba Tuhan Apabila ada sesuatu hal yang terjadi di luar kehendak sebagai manusia saya, menerimanya sebagai kehendak Allah dan kepada saudara-saudara dan keluarga tidak boleh menuntut Hamba Tuhan yang telah melayani saya. Saya menerima pelayanan secara Kristiani karena saya :

1.

2. 
Demikianlah pernyataan ini saya isi dan tanda tangani dengan sesungguhnya semoga Hamba Tuhan dapat melayani saya tanpa raguragu, sekian dan terima kasih.

Tanggal

Yang Membuat Pernyataan

(

\section{Bimbingan Mengenal Penyakit yang Berasal Dari Iblis}

Tubuh manusia terdiri dari tiga bagian yakni tubuh, jiwa, dan roh. Dari ketiga bagian ini masing-masing mempunyai penyakit dan harus di rawat sesuai dengan penyakitnya. Penyakit tubuh atau penyakit biasa di rawat di rumah sakit umum, penyakit jiwa di rawat di rumah sakit jiwa dan penyakit roh jahat tidak ada rumah sakitnya hanya dapat di sembuh oleh Hamba-hamba Tuhan yang di beri karunia kesembuhan.

Menurut Simon Sampe Randan, dalam Tabloid pelayanannya bahwa:

"Ciri-ciri penyakit yang ditimbulkan roh-roh jahat:

1. Dilihat dari segi mental.

Orang sakit menderita sakit hati, sakit leher, sakit kepala, susah tidur, mendengar suara-suara, mendengar bisik-bisikan, rasa ketakutan, gelisah, mau mati rasanya, ia mau bunuh diri, mau lari dari rumah, suka marah tanpa sebab, cepat tersinggung, matanya melotot, dan lai-lain.

2. Dilihat dari segi rohani.

Orang sakit tidak bisa berdoa, ada yang berdoa tetapi hampa, tidak suka baca Firman Tuhan, tidak mau dengar lagu-lagu rohani, tidak mau ke gereja dan suka di tempat yang gelap, dan lain-lain.

3. Sudah keluar masuk rumah sakit.

Orang sakit sudah ke dokter bahkan sudah keluar masuk rumah sakit tetapi tidak sembuh-sembuh dan dokter tidak menemukan penyakitnya, itu berarti ada kemungkinan penyakitnya di timbulkan oleh roh jahat.

4. Dioles dengan minyak.

Orang sakit di oles dengan minyak berdasarkan Yakobus 5:13-16 dan Markus 6:12-13. Telah menjadi pengalaman bahwa pada waktu orang di oles dengan minyak dengan nama Yesus kalau itu penyakit biasa orang sakit tidak sakit di oles tetapi kalau itu dari roh jahat tangan, dan kaki dioles dengan minyak orang sakit itu akan berteriak dan kesakitan sampai roh jahat itu keluar. Dan kalau roh jahat keluar orang sakit itu langsung rasa legah seperti beban yang telah terlepas. 


\section{Bimbingan Mengenal Penyebab Penyakit}

Alkitab dengan jelas memberitahukan kepada kita bahwa persoalan sakit penyakit adalah sesuatu yang kait mengait dengan dosa, dengan pekerjaan Iblis dan dengan kematian secara rohani, artinya :

1. Ada orang yang sakit karena dosa yang ia perbuat sendiri atau dosa yang dibuat orang tuanya. Lihat dalam Yohanes 5:5,14, Mazmur 103:3-4, Mazmur 107:17-18.

2. Ada orang sakit karena pekerjaan Iblis atau Setan dapat di lihat dalam Kisah Para Rasul 10:38, Markus 9:17, 20, 25, Kisah Para Rasul 19:11-12.

3. Ada orang yang sakit karena mati rohaninya dan tidak pernah ke gereja, tidak pernah beribadah kepada Tuhan. Di serang penyakit atau Iblis ia tidak memiliki kemampuan menahan serangan. Lihat dalam Yesaya 59:2, Yakobus 1:5-8.

Dari ketiga masalah ini diperhadapkan kepada semua manusia di dunia ini tetapi Puji Tuhan, Tuhan Yesus mengatakan dalam Matius 1l:28 : “ Marilah kepada-Ku semua yang letih lesuh dan yang berbeban berat Aku akan memberikan kelegahan kepadamu. Yesus mengundang semua orang yang letih lesuh dan berbeban berat untuk datang kepadaNya karena di dalam Dia telah tersedia:

1. Darah-Nya yang sanggup menghapus dosa, menyucikan hati nurani dari perbuatan yang sia-sia dan menebus kita dari kuasa Iblis, lihat dalam Ibrani 9:14, 1 Yohanes 1:9, Yakobus 5:16.

2. Bilur-bilur-Nya, yang menaggung penyakit kita dan kelemahan kita (Matius 8:16-17, 1 Petrus 2:24, Yesaya 53:3-5).

3. Dengan kematian-Nya, Ia merobohkan tembok pemisah yaitu perseteruan dan membinasakan pekerjaan Iblis (Efesus 2:14-15, 1 Yohanes 3:8-10)

4. Dengan kebangkitan-Nya dari antara orang mati menjamin hidup yang kekal kepada setiap orang yang percaya kepadaNya (1 Yohanes 5:13, Roma 10:9-10, Yohanes 14:6)

Setiap orang yang sakit apakah karena dosa atau karena pekerjaan Iblis atau karena mati rohaninya akan ditolong oleh Tuhan Yesus apabila: "mengakui dosanya, menyesali dosanya, dan berjanji tidak akan mengulanginya lagi serta ia mengakui Yesus adalah anak Allah dan percaya bahwa Yesus adalah Tuhannya dan Juruselamatnya.

\section{Bimbingan Mengenal yang Menyembuhkan}

Setiap orang yang mau menerima pelayanan secara kristiani ia harus mengenal yang menyembuhkan. Yang menyembuhkan bukan pendeta, bukan doa pendeta dan bukan minyak yang dipakai mengoles orang sakit tetapi yang menyembuhkan adalah Yesus Kristus. 
Menurut A. B Simpson bahwa:

Kesembuhan ilahi merupakan bagian dari pada penebusan Yesus Kristus, yaitu salah satu anugerah yang di berikan oleh Yesus Kristus. Kesembuhan ilahi di dasarkan pada salib Golgota. Dia yang menebus hidupmu dari liang kubur (Mazmur 103:4) lepaskan dia supaya jangan ia turun ke liang kubur, uang tebusan sudah ku perolah (Ayub 33:24). Sesungguhnya, kesembuhan itu datangnya dari Dia semata-mata. Oleh bilur-bilurNya kita jadi sembuh (Yesaya 53:5). Itulah karya penebusan Kristus. Sebab itulah saudara-saudaraku anda mempunyai hak dalam hal itu oleh sebab tubuh Kristuslah yang menanggung hutang dosa di atas kayu salib. Terimalah kuasa kesembuhan ilahi,... Bahwa segenap tubuh Kristus telah di siksa begitu rupa sehingga seluruh tubuh itu merupakan suatu bilur saja. ${ }^{19}$

Dari penjelasan A. B Simpson ini penulis mengatakan benar sekali penyembuhan itu adalah bagian dari pengorbanan Yesus Kristus dan merupakan salah satu anugerah yang diberikan oleh Yesus Kristus kepada kita, sehingga kebenaran mengatakan dalam Mazmur 103:4 bahwa Dia yang menebus hidupmu dari liang kubur, Dia juga yang melepaskan sehingga kita tidak turun ke liang kubur karena uang tebusan telah di peroleh (Ayub 3:24). Jadi kesembuhan itu datangnya dari Yesus Kristus karena oleh bilur-bilurNya kita menjadi sembuh. Dengan kata lain bahwa semua orang yang mau di sembuhkan harus mengenal Yesus Kristus dan menerimaNya sebagai Tuhan, sebagai Juruselamat, sebagai Tabib, dan sebagai Imanuel ( Yohanes 15:7, Ibrani 11:6, Yohanes 14:13-14, Mazmur 66:16-20). Di luar dari pada Yesus tidak ada seorang pun yang berbuat apa-apa tetapi bersama dengan Yesus akan dapat melakukan pekerjaaan yang gagah perkasa (mazmur 60:14, Yohanes 15:7, Roma 8:31-37). Siapakah Yesus sebenarnya. Yesus sebenarnya menurut Alkitab Dia adalah Allah sendiri yang telah datang kedalam dunia menjadi manusia, merendahkan diri, dan taat sampai mati di kayu salib (Yohanes 1:1,14, Filipi 2:6-8,). Alkitab juga menjelaskan bahwa Yesus itu adalah Allah yang berasal dari sorga (Yohanes 3:31, Yohanes 6:38).

\section{Bimbingan Mengenal Dosa}

1. Apakah itu dosa?

Dosa menurut Firman Tuhan ialah

- Pelanggaran hukum Allah ( 1 Yohanes 3:4)

${ }^{19}$ A.B. Simpson, Injil Empat Berganda (Bandung: Yayasan Kalam Hidup. 1993), 34. 
- Keinginan melakukan kejahatan dan di buahi maka lahirlah dosa (Yakobus 1:15)

- Perbuatan yang tidak berdasarkan iman ( Roma 14:23)

- Mengetahui kebenaran tapi tidak melakukannya itu adalah dosa (Yakobus 4:17)

2. Akibat dari dosa?

Dosa menyebabkan manusia tidak ada artinya dihadapan Tuhan dan Allah menyembunyikan dirinya terhadap manusia yang berdosa dan pada waktu manusia berdosa berdoa, dosanya bangkit bersaksi melawan dia di hadapan Tuhan. Jadi supaya kita berarti di hadapan Tuhan, Firman Tuhan mengatakan "hendaklah kamu jadi ciptaan baru itulah yang ada artinya, (Galatia 6:15) dan jika kamu tidak bertobat kamu semua akan binasa (Lukas 13:3), hendaklah kamu saling mengaku dosamu dan saling mendoakan supaya kamu sembuh.

\section{Bimbingan Mengakui Dosa}

Apakah saudara pernah melakukan dosa yang terdaftar di bawah ini? Segeralah mengakui supaya Tuhan mengampuninya dan mendengar doa yang kita panjatkan kepadanya. Beberapa contoh daftar dosa itu adalah sebagai berikut.

1. Dosa perzinahan, kecemaran

2. Dosa bertanya pada orang mati

3. Dosa bertanya pada peramal

4. Dosa sihir, penelaah, dukun

5. Dosa jimat, guna-guna, mantra

6. Dosa petenung, berhala

7. Dosa kikir, irihati, cemburu

8. Dosa fitnah, menuduh, mengumpat

9. Dosa bohong, menipu orang

10. Dosa mabuk anggur, tuak

11. Dosa bertengkar, berkelahi

12. Dosa perseteruhan

13. Dosa bimbang, ragu-ragu

14. Dosa mengutuk orang lain

15. Dosa pada orang tua

Semua contoh dosa tersebut diatas dapat dilihat dalam Kitab Ulangan 18:10-14, Roma 1:18-32, Galatia 5:19-20, Wahyu 18:10-14, Kolose 2:15, I Korintus 10:10, Wahyu 21:8, I Korintus 6:9, 10, dan lihat I Yohanes 1:9 dan Yakobus 5:16. Saudara dapat menambahkan daftar dosa diats sesuai dengan kebutuhan pastoral. 
Doa untuk Orang yang Sakit

1. Menyanyi "dosa dapat dihapus, hanya oleh darah Yesus"

2. Doa pengampunan dosa dan doa menerima Yesus sebagai Tuhan dan Juruselamatnya

3. Doa pelepasan dari kuasa Iblis

4. Doa pemulihan kembali

\section{Bimbingan Sesudah Pemulihan}

Setiap orang yang sudah didoakan harus kembali memperhatikan Matius 12:43-45. Dalam Matius ini Tuhan Yesus menyampaikan beberapa hal yang sangat penting :

1. Roh jahat keluar dari manusia dan pergi mencari tempat kalau ia tidak dapat tempat ia akan kembali.

2. Kalau roh jahat itu kembali dan mendapati orang yang sudah di pulihkan berada dalam keadaan kosong, bersih tersapu dan rapi teratur ia akan mengajak tujuh roh lain yang lebih jahat dari padanya dan masuk serta tinggal kembali dalam diri orang yang kosong itu.

3. Akhirnya keadaan orang itu menjadi lebih buruk dari pada semula.

4. Hal ini akan berlaku atas angkatan yang jahat.

Dari penjelasan Tuhan Yesus ini kita mengetahui bahwa Iblis masuk ke dalam tubuh manusia pada waktu ia kosong. Karena itu kepada orang-orang yang telah di pulihkan jagalah dirimu jangan sampai kosong. Untuk menjaga diri kita supaya tidak kosong marilah kita lihat II Korintus 13:5 yang mengatakan:

"Ujilah dirimu sendiri, apakah kamu tetap tegak di dalam iman. Selidikilah dirimu sendiri, apakah kamu tidak yakin akan dirimu, bahwa Kristus Yesus ada di dalam diri kamu? Sebab jika tidak demikian, kamu tidak tahan uji."

Di dalam ayat ini kita tahu bahwa yang harus mengisi diri kita sehingga kita tidak kosong adalah iman yang tetap tegak dan keyakinan bahwa Kristus Yesus ada di dalam diri kita. Tetapi apabila seseorang tidak tegak dalam iman dan tidak yakin bahwa Yesus Kristus ada di dalam dirinya ia pasti tidak akan sanggup menghadapi tantangan atau ia berada dalam keadaan kosong dan iblis akan mengisi tempat kosong itu. Iman yang tegak berarti tidak bimbang, tidak ragu dan tidak kuatir, ia tetap percaya bahwa Yesus itu adalah Tuhan dan Juruselamat.

\section{Mengatur Pertemuan Berikut}

1. Pertemuan kedua paling lambat tiga hati dari hari pertama

2. Kalau yang sakit ada kesempatan bisa datang besok 
3. Kalau sebentar malam ada gangguan bisa menghubungan lewat handphone supaya di doakan.

4. Dan lain-lain.

\section{Pelayanan Khusus bagi Orang yang Terlibat Okultisme}

Orang yang terlibat okultisme bararti orang itu adalah pemakai okultisme atau yang terlibat langsung memakai okultisme misalnya: Tahyul, Ramalan, Ilmu Sihir, dan Spritisme. Orang yang terlibat pemakaian okultisme entah satu kali atau berulang kali atau yang sudah menjadi tukang okultisme tergolong orang yang terlibat dalam okultisme. Menurut Ulangan 18:12 bahwa setiap orang yang melakukan hal-hal ini adalah kekejian bagi Tuhan dan oleh karena kekejian-kekejian inilah Tuhan Allahmu menghalau mereka dari hadapanmu. Dari ayat ini penulis mengetahui bahwa orang yang terlibat dalam okultisme adalah kekejian bagi Tuhan karena itu penulis akan memberikan bimbingan khusus kepada orang yang terlibat dalam okultisme.

Cara Bimbingan Untuk Orang Yang Terlibat Okultisme

1. Pembimbing harus menyadarkan orang yang terlibat okultisme tentang bahaya okultisme pada yang mempraktekkan okultisme dan bahaya bagi manusia yang di pengaruhi oleh okultisme dan pembimbing harus mampu menjelaskan Ulangan 18:10-14, 1 Korintus 6:19, 10, Wahyu 21:8.

2. Apabila orang yang terlibat okultisme sadar dan menyesal tentang perbuatannya dan mau bertobat minta benda-benda okultisme yang di pegangnya atau yang di simpannya supaya segera di bakar.

3. Sesudah benda-benda Iblis dibakar orang yang terlibat langsung dalam okultisme maka orang itu harus di bimbing supaya dia mengakui semua dosanya.

4. Dan orang itu harus di tuntun supaya ia menerima Yesus sebagai Tuhan, menerima Yesus sebagai Juruselamatnya, menerima Yesus sebagai Tabibnya.

5. Sesudah itu orang itu harus dibimbing untuk melawan Iblis dalam nama Yesus supaya Iblis tidak akan menganggu terus dengan mengingat kebenaran dalam Yakobus 5:16 "Tunduklah kepada Allah dan lawanlah Iblis maka ia akan lari dari padamu”.

6. Orang itu harus di bimbing dengan bimbingan lanjutan dengan menjelaskan dalam kebenaran Matius 12:43-45, 2 Korintus 13:5, dan Yesaya 9:5. 


\section{PENUTUP}

\section{Kesimpulan}

Pertama, okultisme dalam pelayanan pastoral merupakan bagian yang kait mengait dengan pemberitaan Injil. Manusia harus diinjili supaya menerima Yesus sebagai Tuhan dan Juruselamatnya dan orang yang telah diselamatkan juga harus dilepaskan dari kuasa gelap atau kuasa setan.

Kedua, okultisme dalam pelayanan pastoral menjadi sangat penting bagi pelayanan pastoral karena iblis adalah musuh kita. Oleh karena itu hamba-hamba Tuhan harus yakin bahwa iblis ada dan tetap bekerja memengaruhi umat Tuhan dan harus siap membela umat Tuhan dengan melawan iblis dengan iman yang teguh.

Ketiga, penguraian okultisme dalam pelayanan pastoral adalah merupakan acuan yang dapat dijadikan pedoman oleh hamba-hamba Tuhan dalam mengadakan pelepasan umat Tuhan dari kuasa-kuasa gelap, sehingga umat Tuhan menjadi umat pemenang dari kuasa dosa dan iblis. 


\section{KEPUSTAKAAN}

\section{Alkitab}

Alkitab. Jakarta: Percetakan Lembaga Alkitab Indonesia, 2002.

Alkitab Penuntun.Hidup Berkelimpahan. Malang: Gandum Mas, 1993.

\section{Buku-buku}

Adina Chapman, Pengantar Perjanjian Baru. Bandung: Yayasan Kalam Hidup, 2004

Candlish Mc Phillips. Dunia Roh. Bandung: Kalam Hidup, 1994.

Chia David Pdt. PHK Dengan Iblis. Jakarta: Gunung Mulia

Craig S. Hawkins. Seluk Beluk Sihir. Yogyakarta: Yayasan Andi, 1996

Eka Darmaputera. Tatkala Allah melawat UmatNya. Jakarta: Gunung Mulia, 2010

Gerald R. Mcdermott. Mengenali 12 Tanda Kerohanian Sejati. Yogyakarta: Yayasan Andi .1995

Gobay, John M. Praktek dan Strategi Iblis. Bandung: Kalam Hidup, 1996

Grain Dobbins, dalam John E. Ingouf, Seklumit Tentang Gembala Sidang. Bandung: Lembaga Literatur Baptis, 1988.

John dan Mark Sandford. Pelepasan dan penyembuhan Batiniah. Jakarta: Nafiri Gabriel. 1999.

Larson, Bob. Membongkar Tipu Daya Iblis. Yogyakarta: Yayasan ANDI, 1990.

Mary K. Baxter. Alam Roh. Jakarta: Light Publishing, 2000.

Nehemia Mimery, Rahasia Tentang Penggembalaan (Mimery Press,n.d)

Phillip S, Mc Candlish. Dunia Roh. Bandung: Kalam Hidup, 1979

Prince, Derek. Doa dan Puasa. Jakarta: YPI Imanuel,1992

Randan, Sampe Simon. Tabloid Bimbingan Pelepasan dan Doa Kesembuhan ilahi.

Sappington, Thomas J. Hancurkan Kuasa Iblis Dalam Diri Anda. Yogyakarta: Yayasan ANDI dan OC Internasional, 1998.

Simpson, A. B. Injil Empat Berganda. Bandung: Kalam Hidup, 2012.

Soekahar, H. Satanisme dalam Pelayanan Pastoral. Malang: Gandum Mas, 1983.

Whyte, H. A. Maxwell, Roh Jahat dan Pelayanan Pelepasan. Malang: Gandum Mas, 2000

Wiebe, Warren W. Strategi Setan. Yogyakarta: Yayasan ANDI, 1992.

Ro,Woo Ho. Manusia Kepunyaan Allah. Tangerang: Yayasan YASKI, 2010. 